\title{
The People's Behavior Change During Pandemic of Covid-19; The Four Aspects of Design Thinking
}

\author{
Shahrel Nizar Baharom ${ }^{1, *}$ Saiful Bakhri Mohamed Anuar ${ }^{2,}$ Nur Hazwani Zolkifly ${ }^{3,}$ \\ Hanafi Mohd Tahir ${ }^{4}$ \\ ${ }^{1}$ Faculty of Art and Design, Universiti Teknologi MARA, Perak \\ ${ }^{2}$ Maju Expressway Sdn Bhd \\ ${ }^{3}$ Department of Business Management, Universiti Teknologi MARA, Perak \\ ${ }^{4}$ Faculty of Art and Design, Universiti Teknologi MARA, Perak \\ *Corresponding author e-mail: shahr169@uitm.edu.my
}

\begin{abstract}
The new normal practice i.e. social or physical distancing makes the people is deliberately increasing the physical space between each other, thus driving them to act differently due to restriction and guidelines made by the authorities. Besides, in order to sustain their life, people has to take an alternative measure such as the use of digital technology as substitutes for communication, interaction, learning, playing and working even purchasing. This situation somehow drives the people to change their behavior. Therefore, this paper will discuss the factors and elements of people's behavior change from economic perspective that offer the four aspects of design thinking for artists and designers in producing their artworks and designs.
\end{abstract}

Keywords: Covid-19, design thinking, social distancing, behavior change.

\section{INTRODUCTION}

Social or physical distancing has become the new normal practice for people all around the world. People is deliberately increasing the physical space between them and treat their lives differently in line with the restrictions and guidelines made by the authorities. This pragmatic measure pledged by World Health Organization (WHO) is seems effective to reduce the spread of the Coronavirus or Covid-19 among the people.

By now, most of the countries are in recovery phase which heading to the post-pandemic of Covid-19. However, this is far from our expectation. Most of countries are still struggling in combating the virus without certified vaccine and dither to lift off the lockdown measures although more economic sectors are start to function. However, people is still mindful for their health and safety. Therefore, people has keen to use digital technology as an effective tool for sustaining their life during the contagion situation.

Apparently, people's behavior change is reflected from the pandemic of Covid-19 has embarks the notion of the low touch economy (LTE) where "the new state of our society and economy, permanently altered by Covid19 which characterized by low-touch interactions, health and safety measures, new human behavior s, and permanent industry shifts" [1].

Therefore, this paper will explain the factors and the elements of people's behavior change during pandemic of Covid-19 and its relation to the low touch economy. In addition, this paper also suggests the big ideas of design thinking that artists and designers should embrace in producing more creative and innovative artworks and designs.

\section{PEOPLE'S BEHAVIOR CHANGE DURING PANDEMIC OF COVID-19}

People's behavior change is related to the way of individuals in altering their act and react, thus affects how individuals are functioning as a whole [2]. According to Bandura's Social Cognitive Theory [3], he stated that the people's behavior change is driven by external factors instead of internal factors. This theory also suggested that human is functioning via reciprocal determinism; the triadic interaction of behavior, personal and 
environmental factors. Furthermore, the environmental factor plays a dominant role in this triadic interaction, in which situational or surrounding will influence the preformed behavior and personal factor comprises of instincts, drives, traits, and other individual motivational forces.

Correspondingly, by referring to the Health Belief Model which connected to people's behavior change indicated that the environmental health certainly influences likelihood of the individuals. The individuals shall be adopting recommended health protective behavior if they are facing the health threat. Therefore, the individuals must take personal precaution with susceptible feeling in avoiding the disease, besides taking the preventing action that involves change of behavior [4].

Referring to the pandemic of Covid-19, the gist of Health Belief Model indeed significant to the people's behavior change when human is tending to mitigate their behavior which require significant efforts to strengthen beliefs about disease which includes the severity and susceptibility of threat, eliminate barriers to act and reinforce self-efficacy beliefs [5]. Undeniably, people these days has to take extra precaution by following the health and safety measures advised by WHO followed by the authorities' enforcement to abide with the new normal practice i.e. Social or physical distancing that banned human gathering and close interaction especially in public place.

Nevertheless, people has started to adjust their behavior for sustaining their life into the new normal practice especially in communicating, interacting, learning, working, playing even purchasing. Therefore, the used of digital technology such as internet services and internet-based services have become essential for people to accommodate their needs during pandemic [6]. This can be seen on the spike of internet services usage up to $100 \%$ right after the lockdown started. Besides, the usage of internet-based services such as videoconferencing, online gaming and mobile apps also show substantial increases. Although the lockdown measures are lifted for most countries, the internet services remain high in usage by people across the world [7].

Obviously, it shows that the people's behavior change is effected from the pandemic of Covid-19, in a way that human is tend to alter their behavior as precaution to avoid the infection of the Coronavirus. Henceforth, in order to sustain their life during pandemic, people is incline to use the digital technology, largely on internet services for avoiding close physical contact. Consecutively, it turns to be the factors that lead to people's behavior change in facing the pandemic of Covd-19 as shown in Figure 1.

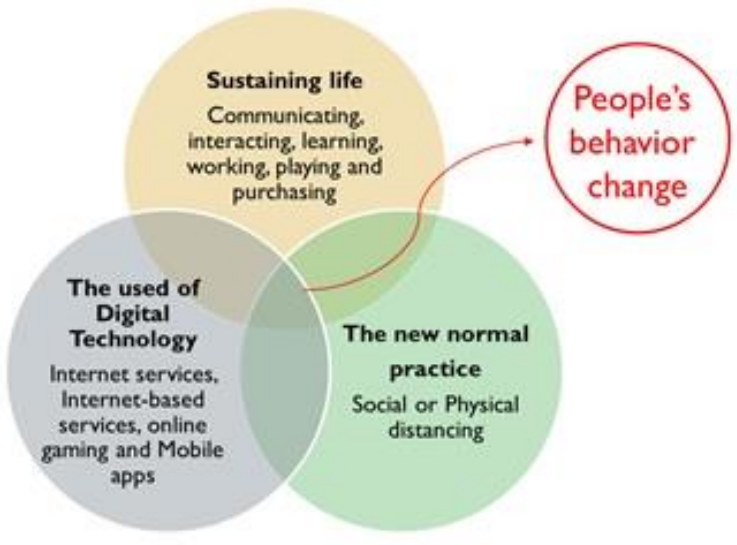

Figure 1 The factors that lead to people's behavior change during pandemic of Covid-19.

\section{THE RELATION OF THE LOW TOUCH ECONOMY AND PEOPLE'S BEHAVIOR CHANGE}

The outbreak of Covid-19 contributes a huge impact to the economic activities since the lockdown measures until the new normal practice has taking place. According to Peterson \& Thankom [8], social distancing policy outraged the economic activities to reduction level and shows negative effect on stock prices. Therefore, the low touch economy (LTE) is significant to be addressed in this study because it will shape a new economy as a result of Covid-19. LTE is conveyed by the group of design firms beneath the name of Board of Innovation that mainly concerned about people health and safety, in the same time propose the right strategies for the industries to take part effectively in economy during pandemic [1].

According to the strategy report, LTE has considered several characteristics as guidelines for industries in operating their businesses during pandemic of Covid-19 which involves business operations toward strict policies, new consumer behavior, prediction of pandemic economy and business model that tailored to the new normal practices. These characteristics have prevailed the meaning of LTE that need to be mindful by many industry players in order to recover and grow which 
resonated from people's behavior change. By looking to the feedback loop of LTE (Figure 2), the people's behavior change appears as a fundamental element that caused by pandemic-control health measures of low touch measures i.e. social distancing resulting the disruption of the economy in macro and micro level which creates fairly unpredictable system [1].

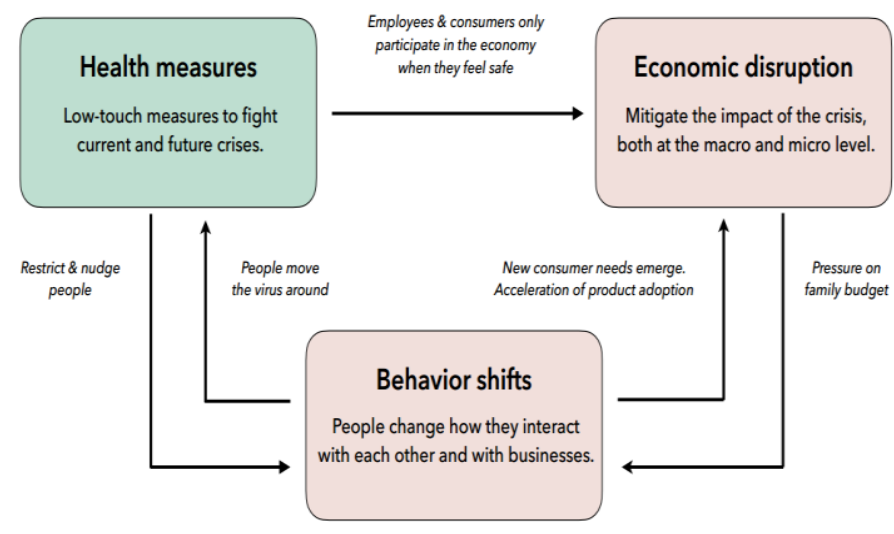

Figure 2 The feedback loop of LTE (Source: Board of Innovation.com)

Furthermore, people's behavior change is measured through the changing of people's interaction between each other and with businesses. Therefore, when people has to act differently during the pandemic i.e. A reduced amount of face-to-face services between retailers and consumers due to social distancing policy engrosses people to demand new things. Accordingly, people is demanding retailers to provide them with digital services such online business and delivery services. This will have required retailers to use e-commerce platform, in which relevance to new consumer behavior and becomes the good opportunities for businesses to sustain in challenging economy.

The new consumer behavior through economy trait shows that people is no longer depends on previous behavior before the outbreak of Covid-19, hence causing them to make fluid decisions; the diverse decisions based on unstable situations [9]. Therefore, this is good to know the elements that drive behavior and behavior al change that influence decision making (Figure 3). The elements comprise of physical context (channels/movement restriction), social context (norms and cultural influence), processing (framing \& integrating new information), motivation (emotion \& identity) and ability (skills \& routines) could be used as a consideration for art and design society in mitigating their design thinking during pandemic of Covid-19 which will explain further in the next section.

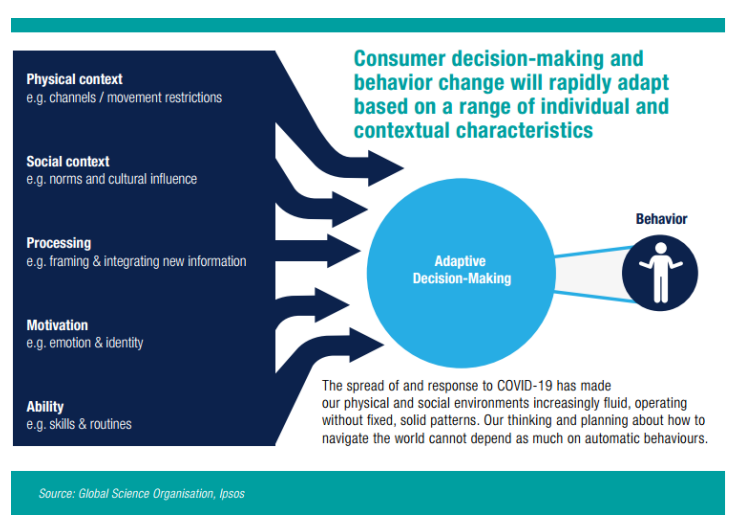

Figure 3 The elements that drive behavior and behavior al change (Source: Global Science Organisation, Ipsos).

\section{THE DESIGN THINKING TOWARDS PEOPLE'S BEHAVIOR CHANGE DURING PANDEMIC OF COVID-19}

Art and design practices should involve the design thinking to understand the people's behavior in order to execute the decent artwork and design representation. The design thinking comprises of six phases with iteration loops such as understanding (empathize), observing, defining problems, finding ideas, developing prototypes and testing [10]. It merely provides solutions and strategies for people which encompass artists or designers to initiate human-cantered based solution [11]. Although art and design practices are generally paying more intention to the visual appearance of the objects [12], but the design thinking respectively required the innovation applies [13]. Therefore, artists and designers should know how to deal with innovation as design solution to cater people's problem and in the same time to fulfil their new needs.

By referring to Figure 3, certainly it provides supporting elements related to Buchanan's [14] idea of design thinking, in which the design should be concerned about one particular set of constraints, possibilities and contingencies. Therefore, the idea of design thinking has been developed based on people's behavior change during the pandemic of Covid-19 that involves three models; (1) The factors of people's behavior change based on researchers' idea, (2) The LTE feedback loop of the low touch economy and (3) The elements that drive behavior and behavior al change.

After scrutinizing the themes and contexts from these three models through compare and contrast approach, the proposed idea of design thinking should be involved four major aspects; (1) Social environment, (2) Psychology, (3) Information and (4) Digital technology as shown in Table 1. 
Table 1. Scrutinizing the factors, LTE feedback loops, elements and design thinking for people's behavior change during pandemic of Covid-19 central theme that shaping thought and value for vindicating the function of human being. This is also implicating the design of complex systems or

\begin{tabular}{|c|c|c|c|}
\hline \multicolumn{4}{|c|}{ People's behavior change during pandemic of Covid-19 } \\
\hline The factors & $\begin{array}{l}\text { The LTE feedback } \\
\text { loop }\end{array}$ & The elements & Design Thinking \\
\hline $\begin{array}{l}\text { Sustaining life } \\
\text { Communicating, interacting, } \\
\text { learning, working, playing and } \\
\text { purchasing }\end{array}$ & $\begin{array}{l}\text { Behavior shifts } \\
\text { People change how } \\
\text { they interact with } \\
\text { each other and with } \\
\text { businesses. }\end{array}$ & $\begin{array}{l}\text { Physical context } \\
\text { (channels/movement } \\
\text { restriction) } \\
\text { Social context } \\
\text { (norms and cultural influence) }\end{array}$ & Social environment \\
\hline $\begin{array}{l}\text { New Normal practices } \\
\text { Social or physical distancing }\end{array}$ & $\begin{array}{l}\text { Health measures } \\
\text { Low-touch measures } \\
\text { to fight current and } \\
\text { future crises }\end{array}$ & $\begin{array}{l}\text { Motivation } \\
\text { (emotion \& identity) }\end{array}$ & Psychology \\
\hline $\begin{array}{l}\text { The use of Digital Technology } \\
\text { Internet services, internet- } \\
\text { based services such as video- }\end{array}$ & $\begin{array}{l}\text { Economic Disruption } \\
\text { Mitigate the impact } \\
\text { of the crisis, both at }\end{array}$ & $\begin{array}{l}\text { Processing } \\
\text { (framing \& integrating new } \\
\text { information) }\end{array}$ & Information \\
\hline $\begin{array}{l}\text { conferencing, online gaming } \\
\text { and mobile apps }\end{array}$ & $\begin{array}{l}\text { the macro and micro } \\
\text { level }\end{array}$ & $\begin{array}{l}\text { Ability } \\
\text { (skills \& routines) }\end{array}$ & Digital Technology \\
\hline
\end{tabular}

\subsection{Social environment}

In sociology context, social environment "encompass the immediate physical surroundings, social relationships, and cultural milieus within which defined groups of people function and interact" [15]. In other words, it involves many components influenced by human behavior change which include relationship, institution, culture, physical structures and ecological. By some means, social environment covers all aspects of social and physical aspects of human being. As mentioned earlier in regards to the factors, the LTE feedback loop and elements of people's behavior change during pandemic of Covid-19, the design thinking for social environment should be focused on how people should function and interact toward the limitation of movement and interaction caused by social or physical distancing.

By referring to the notion of design thinking mentioned by Buchanan [14] shows that the limitation of people's movement and interaction turn out to be a

environments for living, working, playing and learning particularly in pandemic situation.

Besides, the role of design in this context should concern about sustaining, developing, and integrating human beings by emphasizing on communication aspect for strengthening interaction of the people within the constraint circumstances. Nonetheless, the knowledge and skills in visual communication design are required to support the design thinking for social environment in producing the great design and clear information with good strategy and approach for people.

\subsection{Psychology}

The use of psychology in design is undeniable in order to understand the people as user. Besides, parts of psychological knowledge are already available in design theory i.e. Gestalt principles, colours psychology, visceral reaction etc. [16]. For the design thinking in psychological aspect is related to embrace empathy for users' problems and identify what they want and need [17]. However, in the context of design thinking for 
pandemic of Covid-19, somehow it could be more than that.

According to Vizard [18], during the pandemic of Covid-19, the design thinking should understand the concept of how motivation works; intrinsic or extrinsic inputs in order to drive people to do certain things. Hence, identified and integrated motivation should engross people's valuable behavior and identity. In addition, the design thinking should embroil basic psychological needs comprises of (1) Autonomy; people needs to feel like they are matter, (2) Competence; people needs to feel effective, (3) Relatedness; people needs to feel connected.

In relation to that, the deeper knowledge and skills in emotional design concept is turn out to be significant. The emotional design concept is related with the emotional systems consist of three interconnected levels; visceral, behavior and reflective. The visceral level involves instinctive quality of human emotion, the behavior level refers to measured human action, while reflective level is related to reflection, conscious thought and generalization matters. In addition, the design of visceral level should trigger people immediate emotional respond through appearances of things, behavior al level has to do with usability and reflective level is connected to realization and intellectualization substances toward the design of the products or services [19].

In this sense, for compelling motivation and basic psychological needs of the people, the design that involves these three levels are supposed to captivate people's positive emotion rather than the negative ones. Therefore, artists and designers should strengthen the design knowledge and skills by adapting the emotional design concept that elicits positive emotion in their artworks and designs.

\subsection{Information}

When the outbreak of Covid-19 between December 2019 and January 2020, people has received abundance of information related to the vulnerability of the virus. However, not all information is legit which lead to misinterpretation by the people. This misinterpretation engrosses the inevitable problem especially in managing the proper preventive measures and health-giving measure to the people [20]. Therefore, relaying the right information is important to make sure people is well informed and act appropriately.

However, in order to relay the right information is not easy. It supposed to be designed well with good design knowledge and skills. According to Pettersson [21] with the intention to relay the right and effective information to the people, there must be the virtuous information design that incorporated facts, influences, methods, practices, principles, processes, strategies and right tools. Besides, information design should incorporate theories or parts of theories from other disciplines. In this sense, information design is required the combination of disciplines from art and science fields.

In the context of pandemic of Covid-19, the information design is supposing to be standard, consistent and effective. Therefore, the design thinking should concentrate on the clarity and consistency of information. Thus, the use of digital technology such as digital services are seems effective for information distribution i.e. texts and emails for the right people at the right time and at a right place.

Phillips [22] has proposed the ideal design thinking process during pandemic consists of understanding and exploration phase (empathize, define and ideate) that involve formulating and designing the right kind of information for people. Then, implementation and materialization phase (prototyping, test and execution) for ensuring the right information is received promptly by the people through multiple channels. As the results, Philips [22] has suggested several design principles of User experience (UX) such as Hick Law’s, Miller's Laws and Von Restorff Effects to reduce "cognitive load" (information overload) and enhance memorable information that beneficial to the people during isolation condition.

\subsection{Digital technology}

Undoubtedly, design thinking involves a primary discipline to cater people's need that not only required designer's sensibility and method, but also ability and skills of using feasible technology [23]. Since that the pandemic of Covid-19 is seems forcing the people to digital technology adoption, it should involve the artists and designers too. Therefore, the digital technology adoption in design thinking process is vital for gratifying people's problem. Besides, blending the digital technology in the design thinking could allow more innovative product and services [22].

However, in gratifying people's problem related to digital technology cannot be narrowed on ability and skills for creating innovative product and services only. The artists and designers could just adopt the digital technology available such as internet-based social networking (social media) i.e. Facebook, instagram, twitter etc. for disseminating the creative artworks and designs.

According to Hitti [24], the artists and designers have endured the social media as a platform to spread the massage for people's safety from the Covid-19 with the sense of changing people's mind-set. They have come out with creative artworks and designs through social media that empower people to make differences in facing the pandemic of Covid-19 to stay home and stay safe during the outbreak of Covid-19. 


\section{CONCLUSION}

Indeed, the people's behavior change is real due to the pandemic of Covid-19. It requires an effective design thinking to solve people's problem reflected from their behavior change. As people is still in the mode of surviving or sustaining their life, an effective design thinking is significant and certainly supports the artists and designers to determine and explore the right design solutions for the people.

Although, this paper is only discussing the four big ideas of design thinking but it is practical to be used as central themes in the design thinking process. Besides, the four aspects of design thinking specifically on pandemic of Covid-19 will offers more discussion from researchers and practitioners from various perspectives in mitigating people's problem and defining their new needs for better improvement of their life throughout the challenging situations for years to come.

In the future works, researchers are planning to cultivate the art and design process related to the four aspects of the proposed design thinking. This should be involved the integration of several design concepts that embark a new conceptual model that would valuable for future design research and practices.

\section{AUTHORS' CONTRIBUTIONS}

Author 1 Dr Shahrel Nizar Baharom is a lecturer in Graphic design and digital media which specialized in Game design. He has profound interest in emotional design research. For that reason, he wrote about the concept of the player-centric emotional design for digital games.

Author 2 Saiful Bakhri Mohamed Anuar serves as Corporate Communications Manager of Maju Expressway Sdn Bhd. He leads the Corporate Communications department and specializes in branding, message development, social marketing, media relations, technical assistance, and multicultural engagement.

Author 3 Nur Hazwani Zolkifly is a lecturer of Business management in UiTM Perak Branch, Malaysia. She is specialized in marketing. She always shows her deep interest in transforming art and design marketing to a new level.

Author 3 Hanafi Mohd Tahir is a lecturer in Graphic design and digital media which specialized in corporate design. His interest is mainly in information communication design research.

\section{REFERENCES}

[1] Board of Innovation (2020). The Low Touch Economy is here to stay. https://tinyurl.com/yxsr84y4 (Accessed 15 August 2020)
[2] Pam M.S. (2013) Behavior Change. https://tinyurl.com/yyjd9pzj (Accessed 12 August 2020)

[3] Bandura, A. (1986). Social foundations of thought and action. Upper Saddle River, NJ: Prentice Hall

[4] Fishbein, M. \& Triandis, Harry \& Kanfer, F.H. \& Becker, M. \& Middlestadt, S.E. \& Eichler, A. (2001). Factors influencing behavior and behavior change. Handbook of Health Psychology Mahwah, NJ: Lawrence Erlbaum. 3-17.

[5] Mukhtar S. (2020). Mental health and emotional impact of COVID-19: Applying Health Belief Model for medical staff to general public of Pakistan. Brain, behavior, and immunity, 87, 28-29. https://doi.org/10.1016/j.bbi.2020.04.012

[6] De', R., Pandey, N., \& Pal, A. (2020). Impact of Digital Surge during Covid-19 Pandemic: A Viewpoint on Research and Practice. International journal of information management, 102171. Advance online publication. https://doi.org/10.1016/j.ijinfomgt.2020.102171

[7] Branscombe M. (2020). The Network Impact of the Global COVID-19 Pandemic. https://tinyurl.com/y2rs5z2m (Accessed 12 September 2020)

[8] Peterson, O. \& Thankom, A. (2020). Spillover of COVID-19: impact on the Global Economy. SSRN Electronic Journal. 10.2139/ssrn.3562570.

[9] Murphy, C., Naert, S., \& Strong C. (2020), Coronavirus \& behavior change: What does it mean for brands?. https://tinyurl.com/yyssx $78 \mathrm{w}$ (Accessed 20 August 2020)

[10] Plattner, Hasso, Meinel, Christoph \& Weinberg, Ulrich (2009): Design-Thinking, miWirtschaftsbuch, München

[11] Melles, G., (2010) Curriculum Design Thinking: A New Name for Old Ways of Thinking and Practice? Proceedings of the 8th Design Thinking Research Symposium (DTRS8) Interpreting Design Thinking, Sydney, 19-20 October, pp. 299-308.

[12] Julier, G., (2008). The culture of design, 2nd edition. London: Sage.

[13] Badke-Schaub, P., Roozenburg, N., \& Cardoso, C., (2010) Design Thinking: A paradigm on its way from dilution to meaninglessness?. Proceedings of the 8th Design Thinking Research Symposium (DTRS8) Interpreting Design Thinking, Sydney, 1920 October, pp. 39-49

[14] Buchanan, R., (1992) Wicked problems in design thinking, Design issues, 8(2), pp. 5-21 
[15] Barnett, E., \& Casper, M. (2001). A definition of "social environment". American journal of public health, 91(3),

465. https://doi.org/10.2105/ajph.91.3.465a

[16] Carbon, C. (2019). Psychology of Design. Design Science. 5. 10.1017/dsj.2019.25.

[17] Kelley, D. and Kelley, T. (2015) Creative Confidence: Unleashing the creative potential within us all. Harper Collins, USA.

[18] Vizard, L. (2020). What the Global Coronavirus Pandemic Can Teach Designers About Designing for Behavior Change. https://tinyurl.com/yy9cszt7 (Accessed 18 September 2020)

[19] Norman, D. (2004). Emotional design: Why we love (or hate) everyday things. New York: Basic Books.

[20] Hua, J., \& Shaw, R. (2020). Corona Virus (COVID19) "Infodemic" and Emerging Issues through a Data Lens: The Case of China. International journal of environmental research and public health, 17(7), 2309. https://doi.org/10.3390/ijerph17072309

[21] Pettersson, R. (2014). Information Design Theories. Journal of Visual Literacy. 33. 1-94. $10.1080 / 23796529.2014 .11674713$

[22] Philips, M. (2020). COVID-19: The Ultimate Design Thinking Use Case. https://tinyurl.com/y32672d7 (Accessed 18 September 2020)

[23] Brown, T., Design thinking, Harvard business review, (2008), 84-92, 141

[24] Hitti, N. (2020). Graphic designers get creative to circulate helpful advice during coronavirus outbreak. https://tinyurl.com/vekhacm (Accessed 20 September 2020) 